\title{
PEMBERDAYAAN KELOMPOK TANI DALAM PEMBUATAN PUPUK ORGANIK BERBAHAN BAKU LIMBAH RUMAH TANGGA
}

\author{
Zainal Abidin ${ }^{1}$, Mojibur Rohman ${ }^{2 *}$ \\ ${ }^{1)}$ Program Studi Agroteknologi, F. Sains dan Teknologi, UNIRA Malang \\ e-mail: zainal.abidin@uniramalang.ac.id \\ ${ }^{2)}$ Program Studi Teknik Mesin, F. Sains dan Teknologi, UNIRA Malang \\ e-mail :mujiburrohman1988@gmail.com
}

\begin{abstract}
Abstrak
Kegiatan pengabdian ini bertujuan untuk memberikan pelatihan keterampilan untuk mengurangi dampak buruk pemakaian bahan-bahan kimiawi di sektor pertanian melalui pembuatan pupuk organik cair yang ramah lingkungan. Pengabdian ini dilaksanakan di Desa Kademangan, Kecamatan Pagelaran, Kabupaten Malang. Setiap kegiatan bercocok tanam, sektor pertanian tidak akan terlepas dari kebutuhan pupuk. Pupuk yang dipakai petani ini mulai dari proses pembuatan benih padi sampai proses panen. Namun, sebagian besar pupuk yang sering digunakan oleh petani adalah pupuk kimia buatan pabrik dengan harga yang mahal. Pemakaian yang tidak bijaksana dan melebihi dosis yang dianjurkan dapat mengakibatkan struktur tanah menjadi keras dan terjadinya proses eutrofikasi di lingkungan perairan. Pada tahun 2010 pemerintah memunculkan wacana global untuk kembali ke alam (back to nature) di sektor pertanian, di antaranya dengan pemanfaatan bahan alam (bahan baku hayati) dan limbah rumah tangga sebagai komposisi penyusun pupuk dan pestisida (pengendali hama dan penyakit). Sistem ini dikenal dengan istilah sistem pertanian organik yang ramah lingkungan. Untuk itu kegiatan ini dilakukan mulai dari pemilihan komposisi bahan yang akan digunakan sebagai pupuk organik, praktik pembuatan pupuk organik cair, serta pendampingan cara mengaplikasikan produk pupuk organik di lahan pertanian. Luaran dari kegiatan ini adalah produk berupa pupuk organik cair dan pestisida nabati yang dibuat sendiri oleh peserta pelatihan dan meningkatkan minat seta motivasi para petani untuk mengembangkan secara mandiri alternatif pupuk organik yang sesuai dengan kebutuhan petani.
\end{abstract}

Kata kunci: pemberdayaan, pelatihan, kelompok tani, pupuk organik.

\begin{abstract}
This community service activity aims to provide skills training to reduce the adverse effects of the use of chemicals in the agricultural sector through the production of environmentally friendly liquid organic fertilizers. This service was carried out in Kademangan Village, Pagelaran District, Malang Regency. For every farming activity, the agricultural sector will not be separated from the need for fertilizer. This fertilizer used by farmers starts from the process of making rice seeds to the harvest process. However, most of the fertilizers that are often used by farmers are factorymade chemical fertilizers at high prices. Use that is not wise and exceeds the recommended dosage can cause soil structure to become hard and the process of eutrophication in the aquatic environment. In 2010 the government brought up a global discourse to return to nature in the agricultural sector, including the use of natural materials (biological raw materials) and household waste as compilers of fertilizers and pesticides (controlling pests and diseases). This system is known as an organic farming system that is environmentally friendly. For this reason, this activity is carried out starting from the selection of the composition of the material that will be used as organic fertilizer, the practice of making liquid organic fertilizer, as well as assistance on how to apply organic fertilizer products on agricultural land. The output of this activity is a product in the form of liquid organic fertilizer and vegetable pesticides that are made by the trainees themselves and increase the interest and motivation of farmers to independently develop alternative organic fertilizers that are in accordance with farmers' needs.
\end{abstract}

Keywords: empowerment, training, farmer groups, organic fertilizer 


\section{PENDAHULUAN}

Tanaman padi (Oryza sativa) merupakan salah satu komoditas yang paling penting di negara berkembang, mayoritas penduduk Indonesia sangat menggantungkan hidupnya dari sektor pertanian. Sektor ini mempunyai peranan yang fundamental dalam pembangunan ekonomi nasional. Upaya untuk membangun sektor ekonomi dalam bidang pertanian dibutuhkan sumber daya alam dan manusia yang berkualitas. Selama ini petani masih menggunakan pupuk kimia buatan pabrik, misalnya ZA, Urea, NPK, dan lain-lainnya. Pada umumnya harga pupuk kimia ini relatif mahal, terutama setelah pemerintah mencabut subsudi terhadap harga pupuk. Keadaan ini semakin diperparah apabila terjadi kelangkaan pupuk akibat keterlambatan pasokan dari distributor.

Penggunaan pupuk kimia selain membutuhkan biaya produksi yang mahal, berdampak negatif juga terhadap lingkungan di sekitar sawah. Pemakaian pupuk kimia yang tidak bijaksana dan melebihi dosis yang telah dianjurkan menyebabkan struktur tanah sawah menjadi keras dan nantinya akan terjadi proses eutrofikasi (melimpahnya unsur hara di perairan) akan menyebabkan ledakan populasi gulma air dan pendangkalan sungai atau sistem perairan lainnya (Tandjung, 2003). Selain itu pemakaian pestisida kimia secara berlebihan akan menyebabkan hama dan penyakit menjadi resisten.

Pada tahun 2010 muncul wacana global nasional dari pemerintah untuk kembali ke alam (back to nature) pada sektor pertanian, diantaranya degan pemanfataan bahan baku alam (bahan baku hayati) dan limbah rumah tangga sebagai komposisi penyusun pupuk dan pestisida (pengendali hama dan penyakit) yang terkenal dengan sistem pertanian organik yang ramah lingkungan. Pupuk yang dihasilkan dalam pertanian ini adalah pupuk organik yang tidak berpengaruh negatif bagi lingkungan. Saat ini banyak dijual di pasaran berbagai macam pupuk organik dengan harga yang sangat bervariasi, ada yang paling murah sampai dengan harga yang paling mahal. Pupuk organik tersebut dibuat dari bahan baku alami, seperti feses binatang, urine sapi, kambing, dedaunan, sedangkan bahan baku dari limbah rumah tangga seperti air cucian beras, potongan sayur dan buah. Semua bahan baku alami tersebut sangat mudah ditemukan di lingkungan sekitar petani, sehingga mampu menghemat biaya produksi dan memperbaiki struktur tanah yang telah jenuh dengan pupuk dan pestisida kimiawi, dan akhirnya dapat meningkatkan produksi petani dan pendapatan petani.

Setiap lokasi daerah pertanian pasti mempunyai potensi bahan baku hayati yang berpotensi untuk dimanfaatkan sebagai pupuk organik dan pestisida nabati yang kedepannya bisa meningkatkan kesejahteraan petani di daerah tersebut. Sumberdaya alami hayati merupakan bagian atau unsur dari lingkungan hidup, yang meliputi keanekaragaman atau kekayaan hayati yang terdapat di suatu wilayah (Tandjung, 2003).

Banyak bahan baku hayati yang melimpah di lingkungan sekitar petani yang dapat dijadikan bahan pupuk organik dan pestisida nabati. Andoko (2008), menjelaskan tentang pembuatan pupuk cair kaya nitrogen dan dari air kelapa, daun wedusan, dan bintil kacang tanah, sedangkan pupuk organik akar kacang tanah, sedangkan pupuk organik cair kaya unsur P dapat dibuat dari batang pohon pisang dan nira atau tetes. Selain itu, pupuk organik cair yang unsur K juga dapat dibuat dari bahan-bahan yang banyak terdapat di lingkungan sekitar petani, yaitu sabut kelapa. Pupuk organik cair ini dapat digunakan untuk tanaman padi, tanaman palawija, dan sayuran.

Berdasarkan latar belakang di atas, banyak terdapat bahan baku hayati di lingkungan sekitar petani, sehingga petani bisa memanfaatkan sebagai bahan dasar pembuatan pupuk organik cair dan pestisida nabati. Oleh karena itu, para petani perlu dibekali dengan ketrampilan dan inovasi baru, serta penanaman nilai dan prinsip agribisnis. Dengan demikian, kegiatan pengabdian ini bertujuan antara lain untuk: 1) memberikan pelatihan dan ketrampilan kepada kelompok petani untuk membuat pupuk organik cair dan pestisida nabati yang ramah terhadap lingkungan sekitar; dan 2) mengetahui efektivitas pelatihan yang diadakan bagi para petani untuk membuat pupuk organik cair dan pestisida nabati yang bahan bakunya terdapat di lingkungan sekitar 


\section{METODE}

Bentuk pelaksanaan pengabdian ini adalah pelatihan pembuatan pupuk organik cair dan pestisida nabati kepada kelompok tani. Kegiatan pelatihan merupakan proses sistematis dengan menggunakan teknik dan metode tertentu dan bertujuan untuk meningkatkan keterampilan dan kemampuan seseorang atau sekelompok orang (Lubis, 2008). Metode pengabdian ini dilakukan dengan cara menyampaikan materi secara teoritis (ceramah) tentang pengenalan bahan-bahan baku alami untuk bahan pupuk organik cair dan pestisida nabati dan potensi yang tinggi mengenai sumberdaya hayati di Desa Kademangan, Kecamatan Pagelaran, Kabupaten Malang. Tahap selanjutnya yaitu demonstrasi dan praktik secara langsung kepada kelompok tani. Untuk melaksanakan praktik, peserta dibagi menjadi 5 kelompok kerja. Masing-masing kelompok tersebut diberikan kesempatan untuk praktik membuat pupuk organik cair dan pestisida nabati sendiri. Kegiatan pengabdian ini dilakukan selama dua hari dengan target 20 peserta.

\section{HASIL DAN PEMBAHASAN}

\section{Hasil}

\section{Tahapan Kegiatan}

Kegiatan pengabdian ini dilakukan dengan mendatangi lokasi kegiatan, yaitu Desa Kademangan, Kecamatan Pagelaran, Kabupaten Malang. Para kelompok petani diundang di salah satu rumah warga, untuk menjalani pelatihan selama 2 hari. Hari pertama disampaikan materi tentang potensi bahan-bahan alami yang bisa dijadikan sebagai bahan untuk pupuk organik cair dan pestisida nabati, selanjutnya dilanjutkan dengan pemberian contoh atau demonstrasi dengan mengolah bahan-bahan hayati untuk dijadikan pupuk organik cair dan pestisida nabati. Setelah para petani paham dan jelas maka, tahap selanjutnya yaitu petani diberikan kesempatan untuk mempraktikkannya sendiri dalam proses pembuatan pupuk organik cair dan pestisida nabati. Pada hari kedua yaitu pendampingan kepada beberapa petani yang mengikuti pelatihan, sampai pendampingan aplikasi penggunaannya pupuk organik cair dan pestisida nabati. Untuk selanjutnya langkah-langkah kegiatan pengabdian dapat dilihat pada gambar 1.

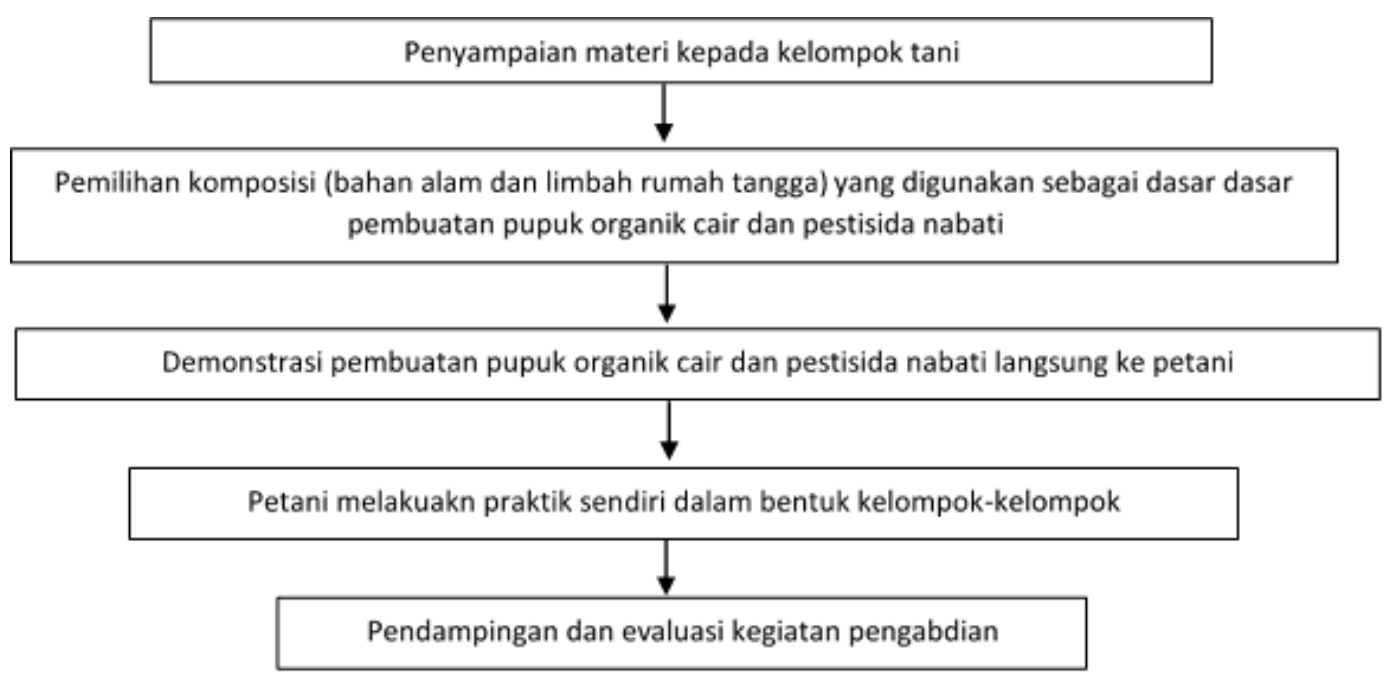

Gambar 1. Langkah-langkah kegiatan pengabdian

\section{Faktor Pendukung dan Penghambat}

Dalam kegiatan pengabdian ini, faktor-faktor pendukng keberhasilan pelaksanakan kegiatan adalah: 1) antusiasme peserta pelatihan untuk mendapatkan pengetahuan dan ketrampilan tentang pembuatan pupuk organik cair dan pestisida nabati yang murah dan ramah lingkungan sebagai alternatif pengganti pupuk kimia buatan pabrik yang harganya semakin mahal dan relatif sulit diperoleh dipasaran; 2) dukungan dari pemerintah setempat (Ibu Kepala Desa, Bapak RT, dan Ketua Kelompok Tani) dengan menyediakan fasilitas tempat dan dorongan semangat kepada 
warganya; dan 3) Tersedianya bahan baku alami dan limbah rumah tangga untuk dijadikan sebagai pupuk organik cair dan pestisida nabati. Sedangkan untuk faktor penghambat dalam pelatihan ini adalah: 1) berkurangnya antusiasme peserta dari golongan remaja dan dewasa dalam pelatihan ini, harapannya golongan remaja dan dewasa ini mampu untuk melanjutkan bertani secara organik orang tuanya; dan 2) 2aktu pelatihan ini bersamaan dengan musim pancaroba sehingga pada hari kedua pelatihan sedikit mengalami gangguan.

\section{Pembahasan}

Kegiatan pelatihan ini diadakan selama 2 hari ini mencakup penyampaian materi (ceramah) dan observasi bahan baku alami dan limbah rumah tangga pada hari pertama, kemudian mempraktikkan secara langsung. Pada hari kedua dilakukan pendampingan kepada petani. Materi yang diberikan kepada kelompok tani meliputi dampak negatif penggunanan pupuk kimia buatan pabrik terhadap lingkungan sekitar, keunggulan pupuk organik cair dan pestisida nabati dibandingkan pupuk kimia buatan pabrik dari segi ekonomi maupun lingkungan, potensi pemanfaatan bahan-bahan alami dan limbah rumah tangga yang digunakan untuk pembuatan pupuk organik cair dan pestisida nabati dan cara pemupukan dan penyemprotan di sawah.

Bahan-bahan yang digunakan dalam pembuatan pupuk $\mathrm{N}$ cair meliputi daun salam $1 \mathrm{~kg}$, daun wedusan (Ageratum conyzoides) $1 \mathrm{~kg}$, air kelapa 1 liter, akar tanaman kacang tanah dengan bintilnya $1 \mathrm{~kg}$, EM-4 $100 \mathrm{ml}$, dan tetes tebu atau gula pasir 10 sendok makan. Berikut cara pembuatannya yaitu menumbuk daun salam, daun wedusan, dan akar kacang tanah menjadi satu, kemudian dimasukkan ke dalam ember dan ditambahkan air kelapa, EM-4, dan tetes tebu atau gula pasir. Setelah itu masukkan larutan tersebut ke dalam tong 35 liter, kemudian tong ditutup rapat dan dibiarkan selama 3 minggu. Selama 3 minggu ini setiap harinya tong ini wajib dibuka sebentar selama 3 menit, ini dikarenakan bakteri yang ada di tong ini bersifat aerob (membutuhkan oksigen untuk bernafas). Kemudian setelah 3 minggu isi tong disaring dan airnya siap disemprotkan ke padi di sawah.

Bahan-bahan yang digunakan dalam pembuatan pupuk K cair diperlukan sabut kelapa $5 \mathrm{~kg}$ dan air 100 liter. Cara pembuatannya yaitu sabut kelapa dicacah dan dimasukkan ke dalam tong yang telah berisi air, ditutup rapat, dibiarkan selama 2 minggu, kemudian disaring dan larutannya siap digunakan.

Bahan-bahan yang digunakan dalam pembuatan pestisida nabati diperlukan yaitu daun mimba $1 \mathrm{~kg}$, daun tembakau $0,5 \mathrm{~kg}$, daun pepaya $1 \mathrm{~kg}$, daun sirsak $0,5 \mathrm{~kg}$, bawang putih $2 \mathrm{~kg}$, serai $3 \mathrm{~kg}$, gadung 0,5 kg, dan EM-4 $100 \mathrm{ml}$. Hancurkan semua bahan meliputi daun mimba, daun tembakau, daun pepaya, bawang putih, serai, gadung, dan daun sirsak. Setelah dihancurkan masukkan cairan dan ampasnya ke dalam tong, selanjutnya masukkan EM-4, gula/tetes, dan air cucian beras lalu diaduk dan tutup sampai rapat. Simpan selama 3 minggu, lakukan pengocokan pagi atau sore kurang lebih 5 menit. Sesekali buka tutup tong selama 3 menit, setelah 14 hari hentikan pengocokan, dan biarkan 7 hari lagi sebelum disemprotkan ke padi.

Para petani selain diberikan pengetahuan dan ketrampilan tentang bagaimana cara pembuatan pupuk organik cair dan pestisida nabati, peserta juga diberikan pengetahuan tentang bagaimana cara mengaplikasinnya pada padi di sawah. Nitrogen ini sangat penting bagi tanaman pada fase pertumbuhan, sehingga pupuk $\mathrm{N}$ organik cair ini sangat baik digunakan pada tanaman padi saat berumur 0-60 hari. Caranya adalah dengan disemprotkan ke tanaman dengan dosis 1 liter pupuk ditambahi 17 liter air, dilakukan seminggu sekali.

Unsur Kalium sangat penting bagi padi untuk proses pembungaan dan pembentukan buah dan biji, sehingga pupuk $\mathrm{K}$ sangat baik diaplikasikan pada saat padi mulai bunting. Caranya mengaplikasikannya yaitu dengan menyeprotkan pada padi secara periodik seminggu sekali, dengan dosis 15 liter pupuk $\mathrm{K}$ cair. Untuk tanaman padi, disemprotkan pada saat padi berumur 60 hari setelah masa tanam sampai sebagian besar bulir mulai mengguning.

Untuk mengaplikasikan pestisida nabati ini bisa disemprotkan seminggu sekali pada padi di sawah yang terserang hama dan penyakit. Caranya adalah dengan disemprotkan ke tanaman dengan dosis 1 liter pestisida nabati ditambahi 17 liter air, dilakukan seminggu sekali.

Setelah diberikan pengetahuan dan ketrampilan pembuatan pupuk organik cair, kemudian dilakukan demonstrasi dan praktiknya. Pada hari pertama dihadiri oleh 20 petani, sedangkan pada 
ari kedua yaitu observasi kepada 15 peserta pelatihan. Adapun beberapa dokumentasi kegiatan pengabdian dapat dilihat pada gambar 2.
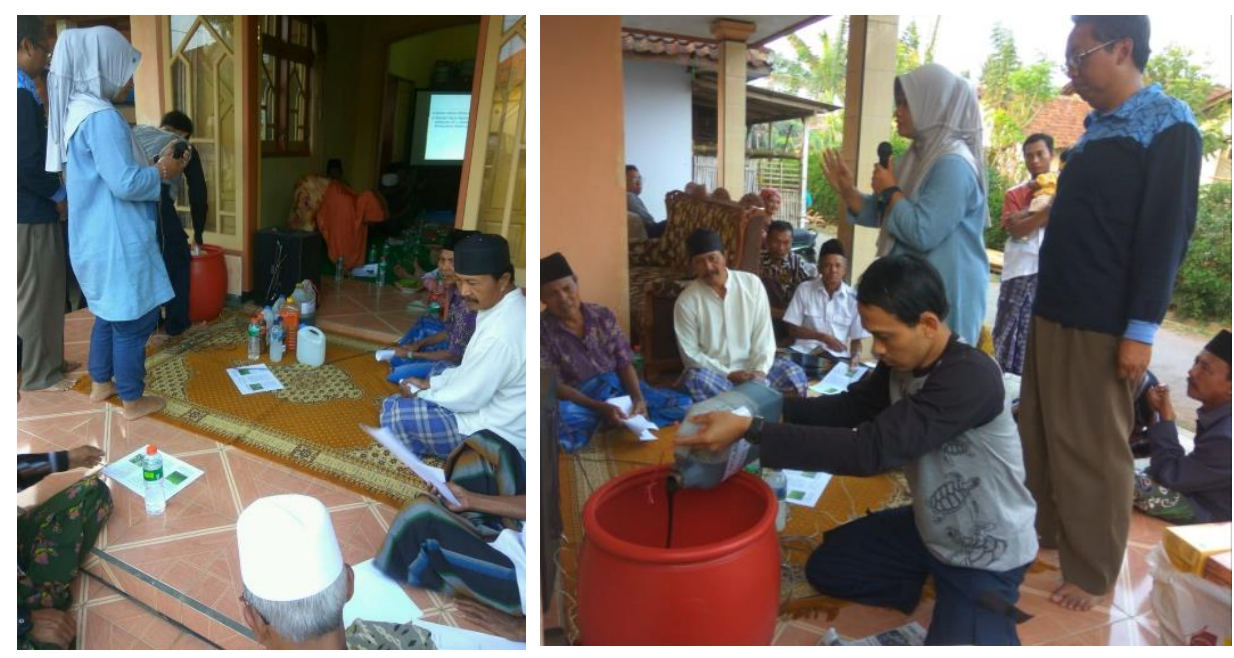

Gambar 2. Pemberian materi kepada kelompok tani dan demonstrasi pembuatan pestisida nabati,

Dalam evaluasi kegiatan ini dilakukan dengan membagikan angket kepada kelompok tani, angket ini wajib diisi oleh peserta setelah acara selesai. Jika dalam pengisian angket peserta mengalami kesulitan dalam memahami dan menjawab pertanyaan dalam angket, peserta pelatihan dibantu oleh mahasiswa dari Universitas Islam Raden Rahmat Malang. Tabel 1 merupakan hasil rangkuman jawaban dari peserta pelatihan.

Tabel 1. Hasil angket yang diisi oleh peserta

\begin{tabular}{|c|c|c|}
\hline No. & Pertanyaan & Persentase jawaban \\
\hline 1. & $\begin{array}{l}\text { Apa yang Bapak Ibu rasakan setelah mengikuti pelatihan } \\
\text { pembuatan pupuk organik cair dan pestisida nabati? }\end{array}$ & $\begin{array}{l}\text { a. Bermanfaat : } 100 \% \\
\text { b. Biasa saja : } 0 \% \\
\text { c. Tidak ada manfaatnya : } 0 \%\end{array}$ \\
\hline 2. & $\begin{array}{l}\text { Pasca pelatihan ini, apakah Bapak Ibu mau untuk } \\
\text { mencoba sendiri mempraktikkan pembuatan pupuk } \\
\text { organik cair dan pestisida nabati di rumah? }\end{array}$ & $\begin{array}{l}\text { a. Ya pasti : } 84 \% \\
\text { b. Ragu-ragu: } 10 \% \\
\text { c. Tidak tahu : } 6 \%\end{array}$ \\
\hline 3. & $\begin{array}{l}\text { Pasca mempraktikkan pembuatan pupuk organik cair dan } \\
\text { pestisida nabati di rumah, apakah Bapak Ibu akan } \\
\text { mencoba mengaplikasikan di sawah? }\end{array}$ & $\begin{array}{l}\text { a. Ya pasti : } 80 \% \\
\text { b. Ragu-ragu: } 16 \% \\
\text { c. Tidak tahu : } 4 \%\end{array}$ \\
\hline 4. & $\begin{array}{l}\text { Bagaimana tanggapan Bapak Ibu mengenai cara-cara } \\
\text { pembuatan pupuk organik cair dan pestisida nabati } \\
\text { sendiri? }\end{array}$ & $\begin{array}{l}\text { a. Mudah sekali : } 50 \% \\
\text { b. Sedang (tidak susah tetapi juga } \\
\text { tidak mudah) : } 37 \% \\
\text { c. Susah : } 13 \%\end{array}$ \\
\hline 5. & $\begin{array}{l}\text { Menurut Bapak Ibu, apa keuntungan mengaplikasikan } \\
\text { pupuk organik cair dan pestisida nabati? (dapat menjawab } \\
\text { lebih dari satu jawaban) }\end{array}$ & $\begin{array}{l}\text { a. Lebih murah dibanding dengan } \\
\text { pupuk kimia buatan pabrik: } 88 \% \\
\text { b. Lebih mudah mencari bahannya : } \\
16 \% \\
\text { c. Hasil panen lebih tinggi: } 14 \% \\
\text { d. Tidak ada untungnya : } 0 \%\end{array}$ \\
\hline
\end{tabular}

Dari Tabel 1 diketahui rekapan dari angket bahwa kegiatan ini bermanfaat bagi para kelompok tani. Kegiatan pemberdayaan ini diharapkan dapat menghasilkan luaran berupa pengetahuan dan ketrampilan yang diberikan kepada petani untuk memanfaatkan potensi bahan baku hayati dan limbah rumah tangga yang tersedia di lingkungan sekitar petani, untuk diolah 
menjadi pupuk organik cair dan pestisida nabati yang bersifat ramah lingkungan dan harganya jauh lebih murah daripada pupuk kimia buatan pabrik.

Kegiatan pelatihan ini dikatakan efektif atau berhasil jika minimal $80 \%$ peserta pelatihan bersedia mempraktikkan membuat pupuk organik cair dan pestisida nabati dan mengaplikasikan di sawah mereka sendiri. Berdasarkan pada tabel 1 diketahui bahwa $84 \%$ peserta pelatihan berniat untuk membuat pupuk organik cair dan pestisida nabati sendiri. Hal ini terkait dengan jawaban $50 \%$ peserta menyatakan bahwa membuat sendiri pupuk organik cair dan pestisida nabati adalah mudah, $37 \%$ peserta menyatakan sedang, dan hanya $13 \%$ yang menjawab susah. Hal ini terkait dengan jawaban sebagian besar peserta pelatihan yang menyatakan bahwa penggunaan pupuk organik lebih murah dan lebih mudah dalam mendapatkan bahan dasarnya dibandingkan dengan pupuk kimia buatan pabrik.

Dari kegiatan ini telah dihasilkan produk berupa pupuk organik cair (pupuk cair N, K) dan pestisida nabati yang dibuat sendiri oleh peserta secara berkelompok pada saat pelatihan berlangsung. Selain itu, dari hasil evaluasi dan pendampingan selama 1 bulan setelah pelatihan, lebih dari 50\% peserta telah mencoba di sawah masing-masing. Berdasarkan hal tersebut, kegiatan pelatihan ini telah berjalan efektif dan berhasil dalam upaya pemberdayaan para petani untuk lebih mandiri dalam menyediakan pupuk organik cair dan pestisida nabati yang ramah terhadap lingkungan.

\section{SIMPULAN}

Kegiatan pengabdian dilakukan dengan memberikan pelatihan kepada kelompok tani yang terdapat di Kabupaten Malang tentang pembuatan pupuk organik dengan bahan baku berupa bahan-bahan alami dan juga limbah rumah tangga yang umum dijumpai. Hasil pelaksanaan kegiatan menunjukkan keberhasilan yang terlihat dengan partisipasi aktif dari peserta. Hasil evaluasi survey yang dilakukan juga menunjukkan bahwa sebagian besar peserta (84\%) menyatakan berminat untuk terus melanjutkan proses produksi pupuk organik tersebut.

\section{SARAN}

Berdasarkan hasil yang diperoleh, kami selaku tim pelaksana kegiatan pengabdian mengharapkan kegiatan pelatihan semacam ini dapat diperluas lagi oleh rekan-rekan lain dengan menjangkau kelompok-kelompok tani di daerah lain, khususnya di Kabupaten Malang, Jawa Timur.

\section{UCAPAN TERIMA KASIH}

Ucapan terimakasih secara khusus kami sampaikan kepada 1) anggota tim pengabdian masyarakat Unira Malang; 2) tim pengabdian Biologi Universitas Brawijaya Malang yang telah ikut berpartisipasi dan mendukung keberhasilan dari kegiatan pengabdian ini.

\section{DAFTAR PUSTAKA}

Andoko, A. 2008. Budidaya Padi Secara Organik. Jakarta: Penebar Swadaya.

Lubis, A.U. 2008. Kelapa Sawit (Elaeis guineensis Jacq) di Indonesia Edisi ke-2. Pusat Penelitian Kelapa Sawit. Medan.

Tandjung, S.D., 2003. Ilmu Lingkungan. Yogyakarta: Laboratorium Ekologi, Fakultas Biologi, Universitas Gadjah Mada 